\title{
THE LAND USE ACT AND LAND ADMINISTRATION IN 21ST CENTURY NIGERIA: NEED FOR REFORMS
}

\begin{abstract}
Akintunde Otubu*
ABSTRACT

Land administration is important in the sustainable use and management of land. Despite its importance, however, the administrative structure under the Nigerian Land Use Act is inconsistent and devoid of clarity of functions and purpose. This article examines the administrative structure under the Land Use Act, focusing on its effectiveness in light of the general principles and policy that motivated the promulgation of the Act. Given the observed lacuna and inconsistency in the administration of the Act, the article calls for legislative intervention to review its provisions. It also recommends a uniform right of occupancy regime, single administrative structure for land administration in the country, and a repeal of the governor's adjudicatory powers in the Act.
\end{abstract}

Keywords: Land, Land Administration, Right of Occupancy, Constitution, Reforms

DOI: https://dx.doi.org/10.4314/jsdlp.v9i1.5

\section{INTRODUCTION}

Land administration systems entail the management of land as a natural resource to ensure its sustainable use and development. In other words, they are concerned with the social, legal, cultural, economic and technical framework within which land managers and administrators must operate. ${ }^{1}$ Good practice in land administration benefits not only the present generation, but also posterity. It operates as the instrument

* PhD, Senior Lecturer, Department of Private \& Property Law, Faculty of Law, University of Lagos, Akoka, Lagos, Nigeria. Email: bullet20042003@yahoo.com. Tel: +2348023253416 . The author is grateful to the Trustees of Femi Okunnu Research Grant in Property Law in Nigeria for providing the funds for this research. 
to ensure equitable access to land by stakeholders within the policy framework of a country. ${ }^{2}$ Furthermore, it determines how the system can offer security of tenure and how government can regulate land markets, implement land reform, protect the environment and levy land taxes to enhance the utility and value of land. A good land administration system will not only guarantee ownership and security of tenure, support land and property taxation, provide security for credit, develop and monitor land markets, and reduce land disputes, but it will also facilitate land reform, improve urban planning and infrastructure development, and support environmental management. ${ }^{3}$ These positive indices of good land administration need to be seen in Nigeria given the need to diversify the country's oil-dependent economy and encourage more private investments, particularly in agriculture and infrastructure development. Thus, a pristine examination of the law on land administration in Nigeria under the Land Use Act ${ }^{4}$ is imperative at this inauspicious period of national life.

The Land Use Act, promulgated in 1978, was motivated by the need to make land accessible to all Nigerians; prevent speculative purchases of communal land; streamline and simplify the management and ownership of land; make land available to governments at all levels for development; and provide a system of government administration of rights that would improve tenure security. ${ }^{5}$

To achieve the foregoing objectives of the Act, various provisions are made in the law to fast-track a seamless administration and implementation of the policy of the Act. However, after 40 years of implementing and administering the Act, one could say that the Act has failed to achieve its set objectives. It is well-known, for instance, that the Act divests citizens' freehold title to their land. And, of course,

1 Daniel Steudler, Abbas Rajabifard, and Ian P Williamson, "Evaluation of Land Administration Systems" (2004) 21 Land Use Policy 371.

2 AN Ukaejiofo, "Perspectives in Land Administration Reforms in Nigeria" (2008) 2 Journal of the Environment 43.

3 See generally, Gershon Feder and David Feeny, "Land Tenure and Property Rights: Theory and Implications for Development Policy" (1991) 5 The World Bank Economic Review 135; Ian Williamson and others, Land Administration for Sustainable Development (1st edn, ESRI Press 2010).

4 Land Use Act 1978, The Complete 2004 Laws of Nigeria <http:// lawsofnigeria.placng.org/view2.php?sn=228> accessed 19 June 2018. (Land Use Act 1978).

5 ibid preamble. 
this is antithetical to their economic prosperity as land ceased from being an article of commerce upon the commencement of the Act. ${ }^{6}$

Administratively, the Act created a monstrous fiefdom in the governor of the state and confounded the roles of the local government and state in land administration in Nigeria.

The current administrative structure provided in the Act stifles land equity and denude tenure security. All these are antitethical to good land administration. These incongruous administrative apparatus in the Act contributed in no small measure to the non-realization of the lofty ideals of land administration and its inherent benefits in Nigeria. Insecurity of title, endless litigation, a skewed property tax regime and stunted mortgage finance market are the order of the day. In view of the foregoing, this article examines the land administration regime under the Land Use Act. It discusses the composition, powers and relationship between the administrative structures established by the Act, vis-à-vis their usefulness and efficiency. Also, the powers of the governor and the local government, in this regard, and their impacts on seamless land administration in Nigeria are further examined here. The article espouses land administration from legislative (regulatory), executive (administrative) and judicial (adjudicatory) perspectives, as provided under the Act, and considers academic, judicial and public comments on the provisions of the Act in this respect. It highlights the problems caused by the current administrative structure and proffers some reforms to address the identified shortcomings in the law.

Accordingly, this article is divided into five sections. After this introduction, section 2 provides a background on the legal framework on land administration in Nigeria. Section 3 analyses the institutional framework for land administration under the Land Use Act, particularly the relationship between the tripod administrative structures of the National Council of States, the State governor and the Local Government. Section 4 identifies gaps in extant legal and institutional arrangements on land administration in Nigeria and the need for reforms. Section 5 is the conclusion.

6 Matthew E Nwocha, "Impact of the Nigerian Land Use Act on Economic Development in the Country" (2016). 8 Acta Universitatis Danubius. Administratio 117. 


\section{LEGAL FRAMEWORK ON LAND ADMINISTRATION IN NIGERIA: BACKGROUND}

The current law on land administration in Nigeria is the Land Use Act. Hitherto, there existed separate and different land policies and administration in the different parts of Nigeria. In southern Nigeria, the policy was dualism with customary land tenure system operating side-by-side and at times overlapping with the English land tenure system enacted as State Land Laws. ${ }^{7}$ The Northern policy was characterized by a paternalistic system, which essentially nationalized all lands by turning former owners into tenants as enacted in the Land Tenure Law. ${ }^{8}$ This fragmented land policy framework was fostered and encouraged by the fact that there was no national land policy for the whole country irrespective of the importance of land to the development of the nation. Furthering this haphazard arrangement was the fact that land matters and management was regarded constitutionally as a residual matter within the legislative competence of the various states that constitute the country, a position which encouraged the development of multifarious land legislation and policies in the country. ${ }^{9}$ This state of flux with respect to land policy and management in the country continued until the promulgation of the Land Use Act in 1978, which subsequently introduced uniform land tenure legislation throughout the country but, unfortunately, without a uniform administrative and implementation policy. ${ }^{10}$

7 The Land Tenure Law of Northern Nigeria of 1962. A law enacted to replace the Land and Native Rights Act of 1916. The land Tenure Law provided that all lands in each of the states in Northern Nigeria whether occupied or unoccupied are "native lands" and are placed under the control and are subject to the disposition of the Minister responsible for land matters, who holds and administers them for the use and common benefits of the natives in Northern Nigeria.

8 This was the law enacted by states in the southern part of Nigeria prior to the promulgation of the Land Use Act to regulate lands owned by the States as opposed to land owned by private citizen, which was primarily regulated by customary land tenure practice and the principles of the English common law.

9 Muiz A Banire, Land Management in Nigeria: Towards a New Legal Framework (Ecowatch Publication Lagos 2006) 84.

10 P. Z. Datong, "The Role of State Government in the Implementation of the Land Use Act" in Olayide Adigun (ed) The Land Use Act: Administration and Policy Implication; Proceedings of Third National Workshop (University of Lagos Press 1991) 64. 
The Act addresses four important issues arising from the former land tenure systems in Nigeria. These are lack of uniformity in the laws governing land-use and ownership; uncontrolled speculation in urban land; access to land rights by Nigerians on equal legal basis; and fragmentation of rural lands arising either from the application of traditional principles of inheritance and/or population growth or the consequent pressure on land. It approaches these issues via three related strategies, namely, the vesting of proprietary rights in land in the State; the granting of usufructuary rights in land to individuals; and the use of an administrative system rather than market forces in the allocation of rights in land.

The Land Use Act created a right of occupancy regime in place of the hitherto unrestricted property rights. It vests all lands within a state in the governor but created a two-level management structure; one at the level of the state governor and the other at the local government level. It also recognized the dichotomy in the existing land rights, which birthed the concept of actual grant ${ }^{11}$ and deemed grant of rights of occupancy ${ }^{12}$ under the Act. Whilst trying to remedy the inadequacies in the existing laws, the Land Use Act created its own genre of problems in land administration in Nigeria.

11 Actual Grant: An actual grant is naturally a grant made by the governor of a State under section 5 of the Act or a local government under section 6 of the Act; whilst a deemed grant comes into existence automatically by operation of the law. See, Savannah Bank Limited $v$ Ajilo (1989) 1 NWLR (Part 97) 305. See, generally, Prince Nwafuru, Principles and Cases on Deemed Grant of Right of Occupancy < https://www.academia.edu/12623272/Principles_and_Cases_ On_Deemed_Grant_of_Right_of_Occupancy> accessed 25 April 2018.

12 Deemed Grant: This expression, though not specifically defined in the Land Use Act, emerged from the coinage used to express the provision of section 34 of the Land Use Act to describe the right of those who held interests in land in Nigeria before the Act came into force. By the Act, a person in this category continues to hold those interests in the land as if a right of occupancy had actually been granted to him by the State. A holder of a right of occupancy deemed granted by the State. The expression was coined by Prof Jelili A Omotola. Read the Amicus curie submission of Prof Jelili A Omotola in Savanah Bank $v$ Ajilo (1989) 1 NWLR (Part 97) 305. See also, Olayide Adigun (ed) The Land Use Act: Administration and Policy Implication (University of Lagos Press 1991) 171; Akintunde K. Otubu, Land Reforms and the Future of Land Use Act in Nigeria <https://www.researchgate.net/publication/269874624_Land Reforms_and_the_Future_of_Land_Use_Act_in_nigeria $>$ accessed 25 April 2018. 


\section{INSTITUTIONAL FRAMEWORK FOR LAND ADMINISTRATION UNDER THE LAND USE ACT}

By virtue of the provisions of section 4 and the Second Schedule to the Constitution of the Federal Republic of Nigeria 1999 (as amended), which excludes land from the listed items in the schedule, land administration falls within the exclusive residual jurisdiction of the States of the federation. This position is reinforced by the provisions of the Land Use Act, which, though a federal legislation, vests powers to manage lands in the State governors. ${ }^{13}$ The Land Use Act, having vested all lands in the state in the governor, ${ }^{14}$ provides for three pronged but uncoordinated regulatory institutions: the National Council of States, ${ }^{15}$ the State governor, and the Local Government.

The National Council of States is empowered to make regulations for the purpose of carrying the Act into effect in some broad respect. ${ }^{16}$ Apart from sharing regulatory powers with the Council, The governor is also expected to share the administration of land in the State with the local government, assisted by advisory administrative committees set up by the authority. The governor is to be assisted by the Land Use and Allocation Committee and the local government by the Land Allocation Advisory Committee.

To remove the existence of any lacunae in land administration in the transition period, the Land Use Act stipulates in section 4 that the provisions of the Land Tenure Law or the State Land Law, as the case may be, shall have effect with such modifications as would bring those laws into conformity with the Act or its general intendment. ${ }^{17}$ The Act

13 Land Use Act 1978, s 1.

14 ibid. This however excludes all lands belonging to the federal government and its agencies under Section 49 of the Act.

15 National Council of States: This an advisory body set up by the 1999 Constitution of Federal Republic of Nigeria (as amended) comprising the President (Chairman), the Vice-President, all former Presidents and all former Heads of Government of the Federation, all former Chief Justices of Nigeria, the President of the Senate, the Speaker of the House of Representatives, all State Governors and the Attorney General of the Federation.4 The primary function of the body is to advice the President on items listed in the Third Schedule part 1(B) paragraph 6.

16 Constitution of the Federal Republic of Nigeria 1999, s 46(1) <http:// www.nigeria-law.org/ConstitutionOfTheFederalRepublicOfNigeria.htm > accessed 19 June 2018 (Constitution of Nigeria).

17 This provision is in recognition of the dichotomy in land administration that existed between the Northern and Southern Nigeria prior to the promulgation 
excludes all lands vested in the federal government and its agencies under section 49, from the application of the foregoing provisions and vests the ownership and management of all such land in the President or any of his appointees entrusted with such powers. ${ }^{18}$

From the set out, it could be seen from these provisions of the Act that there is dichotomy and overlap in the administrative structure set up under the Act. Contrary to one of its objectives, namely, a uniform land policy, the administrative structure under the Act is devoid of any uniformity, consistency and certainty. Each state is empowered to set up its own administrative structure on land administration, thus encouraging the development of multifarious land regulations in the country. Hence, in Nigeria today, there are as many disparate land administration systems as there are States. ${ }^{19}$ Where there is no administrative structure, the applicable land administrative system will depend on whether the land is in the North or South of Nigeria, or whether the land belongs to the Federal government or its agencies.

Fundamentally, whilst the land vested in the governor is to be held in trust and administered for the use and common benefit of all Nigerians in accordance with the provisions of the Act, ${ }^{20}$ there is no such obligation imposed on the federal government in respect of all lands vested in it by law. Thus, while the governor has a caveat placed on him in respect of his management powers ${ }^{21}$ under the Act; the president can, to a large extent, deal with the land under their care as their personal property. ${ }^{22}$ In fact, there is no administrative structure

of the Land Use Act. It thus indirectly gives fillip to the continued existence of the dichotomy in present-day land administration in Nigeria.

18 The Land Use Act 1978, s 51(2): The powers of Governor under this Act shall, in respect of land comprised in the Federal Capital Territory, Abuja, or any land held or vested in the Federal Government in any State, be exercisable by the President or any Minister designated by him in that behalf and references in this Act to Governor shall be construed accordingly.

19 Ukaejiofo (n 2).

20 Land Use Act 1978, s 1.

21 It is conceded that this restriction on the powers of the governor is more apparent than real, but, at least there is a potential bench-mark against which the governor's performance can be measured.

22 This probably accounts for the unwholesome and unfettered exercise of brute power by land administrators in Abuja in respect of alleged distortion of Abuja master plan. Recently the Minister of Federal Capital Territory (FTC) ordered the demolition of houses in Abuja on Independence Day 1 October 2013. See The Punch Newspapers (Abuja, 2 October 2013). 
in place to guide the management of all federal lands, except the provisions of the Act indirectly extending the administrative structure under the Act to Federal Capital Territory Abuja. ${ }^{23}$

It is thus clear at the outset that the administrative regime and structure bequeathed by the Act is not likely to advance the objectives of land administration as set out in the preamble ${ }^{24}$ to the Act. The justification or otherwise of this position becomes obvious after a dispassionate examination and analysis of the provisions of the Act on the topic, to which this article now turns.

\subsection{The National Council of States}

The Land Use Act empowers the National Council of States to "make regulations for the purpose of carrying the Act into effect particularly with regard to the transfer by assignment or otherwise howsoever of any rights of occupancy, including the conditions applicable to the transfer of such rights to persons who are not Nigerians." ${ }^{25}$ The Council may also make regulations relating to the terms and conditions upon which special contracts may be made under section 8; the grant of certificates of occupancy under section 9; the grant of temporary rights of occupancy and the method of assessment of compensation for the purposes of section 29 of the Act.

In the first instance, the Act by virtue of section 46(2) vests regulatory powers in the National Council of States, a body that has no statutory or management powers over the subject matter. No parcel of land is vested in the National Council of States by the Act or by the Constitution. ${ }^{26}$ Furthermore, though the National Council of States never made any regulations in furtherance of this provision, the provision empowers a National body to make regulations for States, in Land matters, in a federation where land management falls within

23 Land Use Act 1978, s 51(2).

24 Ibid, Preamble. The preamble provides thus: "Whereas it is in the public interest that the rights of all Nigerians to the land of Nigeria be asserted and preserved by law and whereas it is also in the public interest that the rights of all Nigerians to use and enjoy land in Nigeria and the natural fruits thereof in sufficient quantity to enable to provide for the sustenance of themselves and their families to be assured protected and preserved".

25 Land Use Act 1978, s 46(1).

26 Constitution of Nigeria 1999, Schedule 3 para 5 pt 1(B). 
the exclusive legislative jurisdiction of the States. ${ }^{27}$ This raises a fundamental constitutional question. The validity and enforceability of any regulations made under this provision by the Council (if any) will always be suspect and liable to be contested in view of the fact that this regulatory powers is not within the constitutional functions of the Council, and particularly where such regulation is at variance with the State land management objectives. To further confound the issue, there is no provision empowering the Council to enforce the regulations made by it.

The section also empowers the National Council of States to make regulations particularly with regard to the transfer by assignment or otherwise howsoever of any rights of occupancy, including the conditions applicable to the transfer of such rights to persons who are not Nigerians. The exercise of this particular provision foretells a conflict with the provisions of the Acquisition of Land by Aliens Laws ${ }^{28}$ of the various states in the federation, particularly where the regulations are at variance with the provisions of these legislations. The moot point is whether the provisions of a regulation can override the express provisions of an enactment. ${ }^{29}$ The Land Use Act thus created a veritable avenue for dichotomy, conflict and uncertainty in land administration in the country.

\subsection{The State Governor}

The Act vests all land comprised in the territory of each State in the Federation in the governor of the State, in trust, to be administered for the use and common benefit of all Nigerians in accordance with the

27 Land Tenure and Management are not listed in either the Exclusive or the Concurrent Legislative List of the Constitution of Nigeria 1999.

28 For example: Acquisition of Lands by Aliens Edict 1971 Cap 1 Laws of Lagos State, s 1(1)a; Native Lands Acquisition Law, Cap 80 Laws of Western Nigeria, s 3(1)-(2); Acquisition of Land by Aliens Law Cap 2 Laws of Eastern Nigeria, s 4(1)-(2).

29 It is a settled legal proposition that executive instructions cannot override the statutory provisions. See, Comptroller General of Customs and Ors $v$ Gusau (2017) LPELR-42081(SC). See also the Supreme Court of India in C Rangaswamaeah and Ors $v$ Karnataka Lokayukta and Ors, AIR 1998 SC 96. See generally, Elijah O. Okebukola and Abdulkarim A. Kana, "Executive Orders in Nigeria as Valid Legislative Instruments and Administrative Tools" (2012) NAUJILJ 59; D Pearce and $S$ Argument, Delegated Legislation in Australia (4th edn, LexisNexis Butterworths 2012). 
provisions of the Act. ${ }^{30}$ Under the provision of section 3 of the Act, the basis of the control and management of land by the governor or the local government is determined by the designation of land as urban area and confining the undesignated areas to the control of the local governments.

The Land Use Act in section 2 empowers the governor to control and manage land within an urban area only, while the local government is empowered to administer land outside a designated urban area. It is imperative, therefore, that for the governor to control and manage land in the state, there must be a defined territory called urban area clearly spelt out in a gazette. Without the classification or demarcation of an area as urban, the governor has no area of control and management of land in the state, as all lands are presumed to be non-urban area by the Act. ${ }^{31}$ Unfortunately, there has been no nationally approved standard for this demarcation as envisaged by the Act. The National Council of States saddled with the responsibility is yet to come up with any regulation in that respect.

In the absence of clear criteria for qualifying any area as urban, manifest confusion is being experienced in the land management sector of the nation. According to a commentator: ${ }^{32}$

the absence of clear criteria for qualifying any area as urban breeds the problem of uncertainty as to extent of land under the governor's control; appropriateness of certificate to be issued; jurisdiction of courts in the adjudication of land matters; confused land identification processes and administrative conflicts between the governor and the local government amongst others, in the land management sector of the nation.

In the absence of any regulatory standard, States resort to the provisions of section 4 of the Act $^{33}$ and impose different standards and regulations in respect of the designation of areas of the state as urban and non-urban lands. ${ }^{34}$ It is necessary, therefore, to have uniform

30 Land Use Act 1978, s 1.

31 Valentine Ofogba, “Understanding the Land Use Act” (Lawsprings \& Co) < http:/ /lawsprings.com/index.php> accessed 24 December 2016.

32 ibid.

33 The provisions of the section permits adoption of different laws based on Land Tenure Law of the former Northern Nigeria or the various States Land Law.

34 In Lagos State, the governor by a 1981 regulation, declared almost all the lands in Lagos State as urban lands leaving the local government with little or nothing in respect of management of land in the State. 
standards and parameters for designating an area as urban or nonurban in order to move the land reform agenda to the next level.

The Act also invests the governor with enormous management and administrative powers, including the power to grant and revoke right of occupancies; power to issue certificate of occupancy and impose rents on land; power to give and/or withhold consent to subsequent transactions under the Act, among other things. To assist the governor in the exercise of these powers, though in advisory capacity, the Act mandates the governor to empanel a Land Use and Allocation Committee. ${ }^{35}$

\subsubsection{Land Use and Allocation Committee}

Section 2(2) of the Act mandates the establishment of the Land Use and Allocation Committee (LUAC) to help the governor in the management and administration of urban lands under his care. The functions of the LUAC are threefold. These are expressed in the Land Use Act as (i) Advising the State governor on any matter connected with the management of land in an urban area; (ii) Advising the State governor on any matter connected with the resettlement of persons affected by the revocation of rights of occupancy on the ground of overriding public interest; and (iii) Determining disputes as to the amount of compensation payable for improvements on land. ${ }^{36}$

The appointment, composition and the modus operandi of the committee is at the exclusive discretion of the governor. ${ }^{37}$ The Land Use and Allocation Committee shall be presided over by one of its members as may be designated by the governor and, subject to such directions as may be given in that regard by the governor, shall have

35 Land Use Act 1978, s 2(2); See also, Akin L Mabogunje, "Land Reform in Nigeria: Progress, Problems \& Prospects" (The World Bank) < http:// siteresources.worldbank.org/EXTARD/Resources/336681-1236436879081/ 5893311-1271205116054/mabogunje.pdf> accessed 25 April 2018.

36 Bola Fajemirokun, "Land and Resource Rights: Issues of Public Participation and Access to Land in Nigeria" (First Workshop of the Pan-African Programme on Land and Resource Rights, Cairo, Egypt, March 2002) <http:// www.nigerianlawguru.com/articles/land\%20law/LAND\%20AND\%20 RESOURCE\%20RIGHTS\%20IN\%20NIGERIA.pdf> accessed 25 April 2018.

37 See O.O. Ekpu, "The Role of the Local Government in the Implementation of the Land Use Act: The Bendel State Experience" in Olayide Adigun (ed) The Land Use Act: Administration and policy Implication (University of Lagos Press 1991), 49. 
power to regulate its proceedings. The committee shall consist of such number of persons as the governor may determine, but shall include in its membership at least not less than two persons possessing qualifications approved as Estate Surveyors or Land Officers and who have had such qualification for not less than five years; and a Legal Practitioner. ${ }^{38}$ The governor is thus the unquestionable personage in the overall administration of land in the state. In practice, the composition, quality and tenure of the committee has tended to vary over time depending on the government in power and the disposition of the governor. ${ }^{39}$ Commenting on the composition and relevancy of the committee, Omotola ${ }^{40}$ observed that:

It is doubtful whether from the composition and mode of appointment of members of the committees whether any person can ever obtain a satisfactory compensation even for improvements on land compulsorily acquired by government. Since the committee cannot be an independent and impartial tribunal, the provision is not only retrograde but also conflicts with the fundamental principles of natural justice, which requires that a person shall not be a judge in his own cause.

This provision has its genesis in the military antecedence of the Act ${ }^{41}$, which recognizes and exudes despotic authority known to military tradition. The Act is undemocratic in its provision and unrepresentative in its administration. Members of the public and other segments of the society are not represented as of right in the committee, as the law provides no criteria for the appointment into the committee. Furthermore, there is no certainty of tenure for members of the committee; they hold their position in the committee at the pleasure of the governor. Unfortunately, the State legislature cannot curb the excesses of the governor in this regard since it lacks the power to amend and or review the Land Use Act, being a federal legislation. ${ }^{42}$ The Act might have been good under a military regime; it is totally autocratic and unacceptable in a democracy.

38 Land Use Act 1978, s 2(3).

39 Datong (n 10) 64.

40 Jelila A Omotola, "Compensation Provisions of the Land Use Act" (1980) XVI Nigerian Bar Journal 36.

41 The Military regime of General Olusegun Obasanjo in 1978 promulgated with fiat the Land Use Decree. 


\subsubsection{Power to Grant Right of Occupancy}

The Land Use Act empowers the governor to grant statutory right of occupancy and no more. ${ }^{43}$ The governor can only issue a certificate of occupancy in respect of land rights preceding the promulgation of the Land Use Act. ${ }^{44}$ All other powers of the governor flowing from this power of grant are restricted to statutory right of occupancy so granted. The provision of section 5 of the Act is clear and unambiguous in this respect. It reads:

It shall be lawful for the Governor in respect of land, whether or in an urban area-(a) to grant statutory rights of occupancy to any person for all purposes; (b) to grant easements appurtenant to statutory rights of occupancy; (c) to demand rental for any such land granted $^{45}$ to any person.

Thus, the power to grant easements ${ }^{46}$ and demand and review rent by the governor is limited to the grant of statutory right of occupancy. ${ }^{47}$ The governor may, however, impose a penal rent for a breach of any covenant in a certificate of occupancy requiring the holder to develop or effect improvements on the land the subject of the certificate of occupancy and to revise such penal rent as provided in the Act. ${ }^{48}$ This latter power is exercisable irrespective of whether the land is covered by statutory right of occupancy or otherwise; the essential requirement here is that the land is covered by a certificate of occupancy.

By virtue of section 5(1) (f) of the Act, the governor can only impose penal rent for breach of any condition express or implied, where the land is covered by statutory right of occupancy granted by the governor. The implication of the provision is that rights of occupancy not statutorily granted under section 5(1) are excluded from the application

42 The Constitution of the Federal Republic of Nigeria 1999, s 315 integrated the Land Use Act as part of the Nigerian Constitution and subjects its amended process to the rigours of constitutional amendment process.

43 Land Use Act 1978, s 5(1).

44 ibid s 34.

45 Emphasis added.

46 A. Umezulike, "Easements and the Problems of Some Startling Presumptions" (2004) 25 JPPL 1 cf NN Chinwuba, "Easements and the Problems of Some Startling Presumptions: A response" (2009) 27 JPPL 35.

47 The provisions do not extend to lands not granted by the governor, eg Deemed grants.

48 Land Use Act 1978, s 5(1)e. 
of the provisions. In essence, the governor is principally interested in the control and management of lands statutorily granted by him. This postulation further reinforces Omotola's theory ${ }^{49}$ that the Land Use Act intended a dual administrative and management structure; one for actual grant and the other for deemed grant of right of occupancy.

It is also to be noted that in granting the right of occupancy, the governor, by the provision of section 14 of the Act, holds possession concurrently with the occupier. Furthermore, section 11 of the Act gives the governor or any public officer duly authorized by him the power to enter and inspect the land comprised in any statutory right of occupancy or any improvements effected thereupon at any reasonable hour in the daytime. It is evident from the express provision of section 14 of the Act that action in trespass is not maintainable against the governor or his duly authorized officer for such entry because the occupier's possession is not exclusive of the governor's. ${ }^{50}$ It is thus obvious that the power of the governor over the management and control of land varies depending on whether the land is covered by statutory right of occupancy or not, and whether the land is subject of certificate of occupancy or not. This dichotomy, which breeds vagaries in land administration in Nigeria, has great implications for landholders, land administration and property market development.

\subsubsection{Power to Revoke Right of Occupancy}

In the administration of the Act, the governor is empowered to revoke the grant of right of occupancy in deserving cases as stipulated by the Act. ${ }^{51}$ The power of revocation is exercisable irrespective of whether the land is in the urban area, directly under the governor, or non-urban lands, under the control of the local governments. It is also of no moment that the right of occupancy is actual or deemed granted. The governor's power in this respect is exercisable where the land is required

49 See, generally, Jelila A. Omotola, Essays on Land Use Act 1978 (University of Lagos Press 1984).

50 Akapan Sam Adua v Akpan Akpan Udo Udo Essien [2010] 8 ALL FWLR (pt. 535) 361 where the Court of Appeal held that "for a plaintiff to commence an action in trespass, he must show that he is in exclusive possession; exclusive possession in the sense that he does not share his right of possession with any other person. He need not show ownership of the land; proof of actual possession can sustain an action in trespass".

51 Land Use Act 1978, s 28. 
for overriding public interest/public purposes or where the revocation results from the exercise of the penal powers of the governor under the Act. The need for the distinction between the two revocation powers of the governor is premised on the fact that whilst compensation is payable for revocation for over ridding public interest/public purposes, there is no compensation for penal revocations. Also, whilst revocation for overriding public interest/public purposes impacts on all land holders/occupiers, penal revocation affects only rights of occupancy granted by the governor or evidenced by a certificate of occupancy. The exercise and instances of the two powers are further discussed below.

\subsubsection{Revocation for Overriding Public Interest/ Public Purposes}

The governor is mandated under section 28(4) of the Act to revoke a right of occupancy in the event of the issue of a notice by or on behalf of the president, declaring such land to be required by government for public purposes. However, the Act is silent on the consequences of the refusal of the governor to accede to federal government request. Can the federal government enforce the provisions of this section even where the governor has yet revoke the existing rights of occupancy over the land? What happens where the federal government public purpose use of the land is at variance with planning laws and zoning policies of the state? These are moot questions and challenges thrown up by the Act in its provisions and administration. There were cases of disputes between the Federal Government and states over the exercise of this power during the Second Republic in Nigeria. ${ }^{52}$

Recently, the Supreme Court affirmed the supremacy of powers of the state government over the federal government in respect of lands

52 Between 1979 and 1983, the Oyo State Government demolished houses being built by the Federal Government under the Low Cost Housing Scheme. The action was reported to have been taken because the land on which the houses were built was not allocated to the Federal Government by Oyo State Government, and that the Federal Government does not have the right to acquire land directly nor by private treaty from any other individual in the state. Consequently, the projects continue to suffer until may be when the Federal Government secures a court order compelling the Governor to revoke the subsisting rights of occupancy. See, Solomon A Oretuyi, "Public Take Over of Land -Federal and State Rights" in Jelila A. Omotola, (ed) The Land Use Act: Report of the National Workshop (University of Lagos Press 1982) 74-79. 
situated in the states, even where the land is federal land. ${ }^{53}$ The provision makes the cooperation of the state government indispensable to the federal government's acquisition of land for its use. The exigencies of the federal government are thus made subject to the politics and bureaucracy of relevant state government in this respect. There is the need for cooperative federalism and inter-government relationships for the smooth application of this provision.

\subsubsection{Penal Revocation}

The Act, under certain circumstances, confers powers on the governor to revoke or compulsorily acquire land and land rights without compensation. All these are referred to as penal revocation and covers situations where the occupier/holder alienates the right of occupancy without the requisite consent; ${ }^{54}$ where there is a breach of any of the provisions deemed to be contained in the certificate of occupancy; ${ }^{55}$ where there is a breach of any terms in the certificate of occupancy or special contract made by the governor; ${ }^{56}$ and where a person to whom a certificate of occupancy is issued refuses or neglects to accept and pay for such certificate. ${ }^{57}$

The Act prohibits ${ }^{58}$ and makes it unlawful for any person granted a right of occupancy by the governor to alienate his right of occupancy or any part thereof without the consent of the governor. Any purported transfer of possession without the requisite consent is null and void. ${ }^{59}$ In addition, following such transaction, the holder of the right could forfeit it by outright revocation without any compensation. In Savannah Bank v. Ajilo, ${ }^{60}$ the court extended the application of the foregoing provisions to include a deemed grant of a right of occupancy.

The application of this provision imposes double jeopardy on the parties to the transaction. The parties would not only have incurred losses on the account of the transaction being declared void for lack of requisite consent of the governor, but will also forfeit the land and the

53 See AG Lagos States v AG Federation \& 35 Ors (2003) 6 SC (Pt 1) 24.

54 Land Use Act 1978, s 28(2)(a) and (3)(d).

55 ibid s 28(5) (a).

56 ibid, s 28(5)(b).

57 ibid s 28(5)(c).

58 ibid s 22 .

59 ibid s 22(2).

60 (1989) 1 NWLR (Pt 97), 305. 
development thereon to the state without any corresponding obligation to pay compensation. ${ }^{61}$ It is enough for the law to invalidate the transaction without the parties suffering the loss of their property without compensation.

By virtue of section 28(5) (a) of the Act, the governor may revoke a statutory right of occupancy if there is a breach of the provisions which by virtue of section 10 of the Act, ${ }^{62}$ the certificate is deemed to contain, including provision on rent. The governor has the exclusive powers to fix and review rents ${ }^{63}$ and may revoke the right of occupancy for failure to pay the imposed rents. ${ }^{64}$ This makes the governor the lawgiver and enforcer at all times. This is equivalent to executive judgement, which is contrary to the tenets of separation of powers and the rule of law. It is one of the incidences of insecurity of title and tenure under the Act as it leaves the holder of the right of occupancy at the mercy of the governor. ${ }^{65}$

The governor is empowered under Part III of the Act to determine and collect rents on rights of occupancy granted under the Act. It is to be noted that this power is exercisable both on statutory right of occupancy granted by the governor and any other right of occupancy once covered by a certificate of occupancy. ${ }^{66}$ However, under section 17 of the Act, the governor may grant a statutory right of occupancy ${ }^{67}$

61 This is a case of double kill, deterrent but not reformative; it does not allow the parties to remedy their wrongs by reapplying for the governor's consent. The language and tenure of the Act speaks volumes of its military antecedence; a totally undemocratic and autocratic culture. See: Akintunde K. Otubu, "Compulsory Acquisition without Compensation and the Nigerian Land Use Act” [2017] Prop L Rev 200.

62 Land Use Act 1978, s 10 provides as follows:

"Every certificate of occupancy shall be deemed to contain provisions to the following effect: (a) that the holder binds himself to pay to the Governor the amount found to be payable in respect of any unexhausted improvements existing on the land at the date of his entering into occupation; (b) that the holder binds himself to pay to the Governor the rent fixed by the Governor and any rent which may be agreed or fixed on revision in accordance with the provisions of section 16 of this Act."

63 ibid s 6.

64 A joint reading of sections 10(b) and 28(5)a of the Land Use Act suggests this conclusion.

65 Akintunde K. Otubu, "Democratic Land Governance and the Land Use ActNeed for Reforms" (2015) 3 IFJR 679.

66 Land Use Act 1978, s 10(2).

67 Emphasis added. 
free of rent or at a reduced rent in any case in which he is satisfied that it would be in the public interest to do so. The implication of this provision is furthering the dual administration and dichotomy in property rights under the Act as only parties with a grant of statutory right of occupancy can benefit from the exercise of the governor's discretion to the exclusion of others, particularly holders of customary rights and deemed grantees.

To buttress the argument of dual administration under the Act, there is no provision for the payment and/or review of rents in respect of lands covered by customary rights of occupancy or other lands not covered by a certificate of occupancy; there is no concrete administrative and enforcement structure in respect of such lands in the least. In essence, the greater parts of the lands in the states are not covered by this rent requirement. ${ }^{68}$ In fact, the Act seems to be more interested in lands in the urban areas, specifically land covered by certificate of occupancy in so far as the rent provisions do not capture other lands in the state. Unfortunately, this is a drain on the revenue profile of the state and unfair taxation on the part of parties caught by the provisions. Such uncovered lands continue to remain dead assets both to the individual occupant and to the state.

\subsubsection{Adjudicatory Powers}

Under the Land Use Act, the governor is endowed not only with executive powers but also with legislative and judicial powers. He is the main character in the implementation and execution of the policy of the Act. He is also empowered to make rules and regulation under the Act, thus exercising quasi-legislative powers. ${ }^{69}$ The governor also exercises quasi-judicial powers as he sits at the head of the Land Use and Allocation Committee to resolve disputes on adequacy of compensation payable to the victims of revocation of land rights. ${ }^{70}$

68 It has been argued that less than 5 per cent of all land in the Nigeria is covered by the certificate of occupancy regime. The implication is that majority of land holders are outside the property tax net: Akintunde K. Otubu, "The land Use Act and Equity Factor in Property Taxation in Nigeria" (2018) 9 NAUJILJ 217225.

69 Land Use Act 1978, s 46(2).

70 ibid, s 2(2) sets up the "the Land Use and Allocation Committee" which shall have responsibility for advising the Governor on any matter connected with the management of urban lands. Some of the functions of the committee include advising the Governor on any matter connected with the resettlement of persons 
Theoretically, the Land Use and Allocation Committee is independent, as it is presided over by one of its members, but the governor determines the composition, membership, tenure of the committee and regulates its proceedings. ${ }^{71}$ Furthermore, the committee is only advisory, and its recommendation is not binding on the governor. The governor thus has the final say in any matter put forward by the committee. Also, the committee/governor's decision on the quantum of compensation payable for improvement on land under the Act is final. No court shall have jurisdiction to inquire into any question concerning or pertaining to the amount or adequacy of any compensation paid or to be paid under the Act. ${ }^{72}$

The import of these provisions is that the governor combines all the functions of the three arms of government under his control and management. He carries out the executive, legislative and judicial functions with respect to the administration of the Act. This position is contrary to the fundamental tenets of democratic governance as espoused in the principles of separation of powers and the rule of law. ${ }^{73}$

In a democratic setting, the adjudicatory powers of the governor in the implementation of the Act cannot withstand judiciary scrutiny, particularly the finality of the committee/governor's decision on the matter. ${ }^{74}$ The inviolability of the provision has been tested in courts and it is gratifying to note that the court of Appeal in Kanada $v$ Governor of Kaduna State and Another ${ }^{75}$ declared section 47(2) void for being inconsistent with the provision of section 40(1) of the 1979 Constitution of the Federal Republic of Nigeria, ${ }^{76}$ for it denies persons claiming compensation for compulsory acquisition of his property access

affected by the revocation of rights of occupancy on the ground of overriding public interest under Act and determining disputes on the amount of compensation payable under the Act for improvements on land. This latter function is carried out irrespective of whether the land is in urban area or not, including lands under the care of the local government. It is being performed along with their primary duty of advising the governor with respect to land in urban areas.

71 Land Use Act 1978s 2(4).

72 ibid 47(2).

73 Paul R Verkuil, "Separation of Powers: The Rule of Law and the Idea of Independence" (1989) 30 Wm \& Mary L Rev 301.

74 Constitution of Nigeria 1999, s 44.

75 (1986) 4 NWLR (Pt 35) 361.

76 Constitution of Nigeria 1999, s 44. 
to a court of law or tribunal or body having jurisdiction in Nigeria.

Whilst the courts may be striving to align the provisions of the Act to modern-day reality of governance, it is trite that judicial reformation of the law is not only tortuous and laborious, the process may take centuries to materialize and it is a fact that judge-made laws can be as imprecise as the vagaries of the mind. ${ }^{77}$

\subsubsection{Management of Deemed Grant Lands}

The Land Use Act created a right of occupancy as the primary proprietary interest in land in Nigeria. The rights of occupancy created are of two variants: statutory right of occupancy and customary right of occupancy. Both rights of occupancy may be acquired by actual grant from the governor or the local Government, or be deemed granted by the appropriate authorities. The actual grants are found in section 5(1) and section 6(1) of the Act respectively, whilst the deemed grants are covered by the provisions of section 34 and section 36 of the Act.

The management and control of actual grant of right of occupancy is well laid out in several sections of the Act, as a certificate of occupancy issued by the governor usually evidences such a grant. Actual grantee of a right of occupancy has a fixed tenure, liable to pay rents, subject to penal revocation of his right and subject to governor's consent on subsequent transactions amongst other obligations. A deemed grantee of right of occupancy, on the other hand, is not strictly regulated under the Act. Save for the provisions on the need for governor's consent to subsequent transactions and the prohibition of alienation under section 36 of the Act, a deemed grantee is ordinarily free from the stringent and strangulating control of his rights under the Act. ${ }^{78}$

The Act, however, provides a window through which a deemed grantee of right of occupancy may be subject to the management and control of the governor/local government under the Act. This occurs where the deemed grantee voluntarily applies for issuance of certificate of occupancy. ${ }^{79}$ Section 36(3) \& (4) of the Act provides a similar

77 Arthur L Goodhart, "Determining the Ratio Decidendi of a Case" (1930) 40 Yale Law J 161.

78 Otubu (n 12).

79 Land Use Act 1978, s 34(2), (3) and (9) of the Act provide in respect of land in urban area that:

(2) Where the land is developed the land shall continue to be held by the person in whom it was vested immediately before the commencement of this Act as if the holder of the land was the holder of a statutory right of occupancy issued by the Governor under this Act. 
provision with respect to non-urban lands, on application to the local government by the person in whom the land was vested prior to the Act.

Thus, the coming into the management blanket by a deemed grantee of a right of occupancy and the issuance of a certificate of occupancy thereof is predicated on the holder making an application to the respective authority at his discretion. This is unfortunate, as the deemed grantee is not compelled to subject his holdings to the management and control of the State. ${ }^{80}$

Though converting a deemed grant of right of occupancy to actual grant is discretionary on the part of the holder, many holders of a deemed grant are eager to apply to the state for the change of status irrespective of the proprietary limitations of actual grant and the certificate of occupancy issued in evidence thereof. ${ }^{81}$ This state of affairs is not unconnected with the potential economic prosperity of the holder of actual grant of right of occupancy who can use his certificate of occupancy as collateral for advances and certainty of his title to the land.

\subsection{The Local Government}

The local government is the third tier of government in the Nigerian

(3) In respect of land to which subsection (2) of this section applies there shall be issued by the governor on application to him in the prescribed form a certificate of occupancy if the Governor is satisfied that the land was, immediately before the commencement of this Act, vested in that person.

(9) In relation to land to which subsection (5) (a) or (6) (a) of this section applies there shall be issued by the governor on application therefore in the prescribed form a certificate of occupancy if the governor is satisfied that the land was immediately before the commencement of this Act vested in that person.

80 Smith had argued that a deemed grantee applying to register his holding and obtain a certificate of occupancy is not in the same position as a holder of a right of occupancy expressly granted by the governor. According to him, whilst the former will not lose his land for failure to collect the certificate issued in respect of the land; the latter's failure to pay and collect the certificate of occupancy could warrant a penal revocation of his right of occupancy and the loss of the land. See I.O. Smith, "Statutory Requirement of Consent to Mortgage Transactions as an Instrument of Fraud in Nigeria" [2009] JPPL 1.

81 According to the interview conducted in 2014 with Mr. Salami, the Executive Secretary, Land Use and Allocation in Lagos State, not less than 30,000 applications were received annually from holders of a deemed grant wishing to convert their holding to an actual grant. 
federation, coming after the federal government and the state government. At present, there are 774 local governments in Nigeria endowed with constitutional responsibilities as stated in the Third Schedule to the 1999 Constitution. ${ }^{82}$ Management of land under the Land Use Act is divided between the governor and the respective local governments in the state. ${ }^{83}$ Whilst the governor is empowered to manage urban lands, as designated under section 2 of the Act, the local governments are in charge of management of all non-urban lands in the state.

To assist the local government in the management of the land under its care, the Act provides for the establishment in each local government a body to be known as the Land Allocation Advisory Committee which shall consists of such persons as may be determined by the governor acting after consultation with the local government and shall have responsibility for advising the local government on any matter connected with the management of land on which the local government has jurisdiction. ${ }^{84}$ In line with section $6(2)$, the Act empowers the local government to grant customary rights of occupancy to any person or organization for the use of land in the local government area.

The import of the provision is to invest the local government with powers of land administration over lands in its domain, not declared as urban land by the governor. It is, however, to be noted that this provision lacks much substance in view of other provisions of the Act that vests the governor with unfettered powers of management of land irrespective of whether the land is urban or non-urban. ${ }^{85}$ For instance, where the governor, exercising the powers under section 3 , declares all the lands in the state as urban land, there will be no land for the local government to manage and or superintend. Even, where the governor divides the land in the state into urban and non-urban lands, the administrative power vested in the local government by this section is so minute as to be inconsequential. Under the Act, ${ }^{86}$ once the land is subject of statutory rights of occupancy and or certificate of occupancy, its management is beyond the powers of local government irrespective of the location of the land in the State.

82 Constitution of Federal Republic of Nigeria 1999, s7 and 3rd Schedule thereto.

83 Land Use Act 1978, s 2(1).

84 Land Use Act 1978, s 2(5).

85 ibid s 5 .

86 ibid. 
Also, the terms and conditions contained in a certificate of occupancy issued by the governor constitute a contract between the governor and the holder of the certificate, and the local government has no role to play even where the land is under its jurisdiction. Furthermore, the local government cannot grant land for agriculture or grazing without the consent of the governor once the grant is in excess of 500/5000 hectares, respectively. ${ }^{87}$ Additionally, the consent of the governor is required in certain circumstances with respect to the alienation of customary right of occupancy. ${ }^{88}$ Though the local government is empowered to grant customary right of occupancy under section 6 of the Act, it lacks the power to charge fees and/or rents for its exercise, save for the provisions of section 42(2), which makes inferential remarks on it. ${ }^{89}$ This is an inherent contradiction in the Act since the lack of such powers denies the local government a veritable source of revenue to carry out its functions under the Act.

Even where the local government is empowered to compulsorily acquire land, ${ }^{90}$ the power has been so much decimated to be ranked as inconsequential. The local government cannot in the least, revoke any right of occupancy, statutory or customary, except through the agency of the governor. ${ }^{91}$ The local government does not even enjoy exclusive right of occupancy over any such land as the governor retains the suzerainty of all lands. ${ }^{92}$

Given the preceding facts, the power of the local government in respect of land administration under the Act is a mirage or at best puzzling. To a discerning mind, there remain several questions as to what the local government can do over land under its control against the rights of the customary owners. In the absence of legal authority, the local government cannot demand for rents, penal or otherwise

87 The Act provides that "No single customary right of occupancy shall be granted in respect of an area of land in excess of 500 hectares if granted for agricultural purposes, or 5,000 hectares if granted for grazing purposes, except with the consent of the Governor." ibid s 6(2).

88 ibid s 21.

89 The section provides that "Proceedings for the recovery of rent payable in respect of any customary right of occupancy may be taken by and in the name of the Local Government concerned in the area court or customary court or any court of equivalent jurisdiction".

90 Land Use Act 1978, s 6(3)d, 28(2)b and (3)a.

91 ibid s 28(1).

92 ibid 6(4). 
over land held in non-urban areas. ${ }^{93}$ All management powers vested in the local government is circumscribed in one form or the other; in fact, all powers belong to the governor. As earlier pointed out, by vesting some management powers in the local government, the Act creates unnecessary dichotomy and incongruous dilemma in land administration with respect to rights of occupancy and certificate of occupancy. The local government is empowered to grant a customary right of occupancy, ${ }^{94}$ but there is no provision for the issuance of any certificate in respect thereof. This has led to the issuance of a document referred to as "Grant of Right of Occupancy" in some states in the northern part of Nigeria. ${ }^{95}$ In some instances, there have been legal disputes on the status of customary right of occupancy and a statutory right of occupancy, ${ }^{96}$ all to the discomfiture of the populace. The division of administrative powers and rights between the governor and the local government has only succeeded at introducing rancour and confusion in land administration in the country.

To further deepen the discord, the Act mandates the establishment of the Land Allocation Advisory Committee at the local government level but gives the governor the power to constitute the committee in consultation with the local government concerned. It will be practically impossible for the local government to control a body not independently set up by it, particularly where the head of the local government belongs to a different political group from that of the governor. It is also to be noted that where the governor refuses to constitute the committee for any reason whatsoever, the local government is bereft of any remedy

93 Ofogba (n 31).

94 Even where the customary right of occupancy is to be granted under the Act, there is no provision for certainty of duration of the right granted. The provisions of section 8 of the Act on fixation of tenure of right of occupancy relates only to statutory rights of occupancy granted by the governor under section 5(1) of the Act, it does not extend to cover the issuance of customary right of occupancy. In fact, the right of the local government vis-a-vis customary right of occupancy is primarily to record such holdings in its records.

95 In Abuja, the issuance of a "Right of Occupancy" document is very common, though there is no provision for such document under the Land Use Act. See "Proceedings and Communiqué" (International Conference and Exhibition on Housing, Abuja, 2013). Nigeria <http://www.asoplc.com/exco/media/conf/ presentation/> accessed 18 April 2018.

96 Joshua Ogunleye v Babatayo Oni (1990) 4 NILR 272. 
against the governor. The constitution of such a committee is foreclosed where the governor declares all land in the state to be urban land. ${ }^{97}$

In practical terms, the existence and value of the Land Allocation Advisory Committee established at the local government level has been questioned. In the report of a workshop on the Land Use Act, ${ }^{98}$ a commentator ${ }^{99}$ lampooned the rationale for the establishment and powers of the local government and the committee. According to him:

Apart from those already identified, there are other important limitations on the powers of the local government under the Act. These limitations derive mainly from the rather too wide powers of the governor vis-à-vis those of the local government. A governor can, if he wishes, decide to marginalize the role of the local government under the Act or even render it completely impotent and irrelevant. ${ }^{100}$

He rightly concluded that there is no doubt that the local government is not in an enviable position under the Act: "The options are either to remove it entirely from the scheme or to strengthen its present position."101 Unfortunately, the author opted for the latter position in spite of the clear provisions of section 1 of the Act vesting all lands in the State in the governor.

Along the same line of thought, Obele and Nwauche ${ }^{102}$ also observed a world of difference between the committee's statutory functions and its actual operations. The irrelevance of the local government in land management schemes of the state is best captured in the words of Datong that "all lands in the state both urban and rural have been vested in the Governor. Besides, other provisions of the Act indicate that the powers of the local government in relation to rural land

97 This has been the situation in Lagos State since the Land Use Act (Regulations) 1981 was made by the then Governor of Lagos State.

98 Olayide Adigun, The Land Use Act: Administration and Policy Implication (University of Lagos Press 1991).

99 Ekpu (n 37).

100 ibid 47.

101 ibid.

102 D. Obele and E. Nwauche, "The Implementation of the Land Use Act by Local Governments: A Case Study of Okirika and Gokana, Tai Eleme Local Government Areas of Rivers State" in Olayide Adigun (ed.) The Land Use Act: Administration and Policy Implication (University of Lagos Press 1991), pp. 54-59. 
are to be exercised in subservience ${ }^{103}$ to the powers of the Governor."104 This article argues that the local government and all its functions should be deleted from the Land Use Act and be merged with State management powers.

\section{THE NEED FOR REFORM}

The administrative structure put in place under the Land Use Act is inconsistent, and devoid of clarity of functions and purpose. The Act intended a uniform and national land administrative system but created two administrative organs with tripod administrative and regulatory controls. Unfortunately, the Act did not clearly demarcate the powers and responsibilities of these bodies. It ended up superimposing one over the other. The governor became a superpower to the detriment of the local government and the smooth administration of the Act. There is confusion as to the role of the council vis-à-vis the governor in respect of management of non-urban lands since what constitutes non-urban land is vague and at the discretion of the governor.

The Act gave regulatory power to the National Council of States, a body that has since refused to perform the function, leaving the administration of the Act at the discretion of the governor of the various states. The abdication of this responsibility by the Council of States is the remote cause of the current dichotomy in the administration of the Act by various states in the country. It was also observed that the language of the Act with respect to the extent of management powers of the governor is unclear. Sections 5 and 22 of the Act are particularly guilty of this ambiguity. It is unclear from the provisions of these sections whether the governor's power is exclusive to the management of land covered by a grant of statutory right of occupancy or to all rights of occupancy. There is also a dichotomy in the administration of lands covered by an actual grant of right of occupancy and deemed grant of right of occupancy. The issue of unfettered unconstitutional powers vested in the governor concerning compensation matters also came up in the discourse.

The local government is empowered to grant a customary right of occupancy, but there is no provision for the issuance of any certificate

103 Emphasis added.

104 Datong (n 10) 65. 
in respect thereof. There is no provision for land registry at local government level though the Act gave them the custody and management of non-urban lands. It is apparent that there is a difference between the state and local government in respect of land administration in the country though the areas of differences are in a state of flux.

Given the inconsistency observed in the administrative provisions of the Land Use Act and its consequences on seamless land administration in 21st Nigeria, it is suggested that land matters should be moved from the current residual legislative list to concurrent legislative list in order to give it the national outlook, uniformity and consistency it deserves in policy formation and in tandem with Fundamental Objectives and Directive Principles of State Policy enshrined in the Nigerian Constitution. ${ }^{105}$ Land is a natural resource and the ultimate denominator of national life, whose administration and management touches on the life of all citizens in the country. It is therefore incumbent for the country as a unit to be involved in the policy directions of all lands. Whilst land policy may be set at the national level based on the fundamental objectives and directive principles of the nation, the management of land should be invested in the federating units in line with the tenets of true federalism. The power to make regulations vested in the National Council of States should, therefore, be repealed and vested in the states of the federation.

Contrary to the current legal regime under the Act, it is recommended that the dichotomy between the governor and the local government in terms of rights and management of land in the state be abolished. It is recommended that all lands in the state should be vested in the governor and a uniform grant and certificates be issued to all occupiers of land by the state irrespective of the location of the land. The dichotomy between urban and rural land should be jettisoned in favour of a uniform land management system. As a way out, the customary right of occupancy and the compulsory conversion and registration of all deemed grants of right of occupancy should be abolished, after which such land should be declared bona vacanti to be managed in accordance with the provisions of the Act.

With respect to the power of the governor in the composition, powers and operations of the Land Use and Allocation Committee,

105 Constitution of Nigeria 1999, Ch 2. 
there should be a review to capture the present nature of governance in civil society. The committee should be strengthened to ensure the enforcement of its decisions and be made more representative of the diverse interests in the society. Membership of the Committee should include the representative of the governor as the chairperson; members of the state traditional chiefs; lawyers, estate valuers, surveyors (all nominated through their respective professional associations); selected relevant state commissioners; members representing the Community Development Associations (CDAs) (nominated from among the members of the State CDAs); four other members representing the general public appointed by the governor on the recommendation of the simple majority of the members of the state Assembly; and the executive secretary of the Committee appointed by the governor on the recommendation of the simple majority of the members of the State Assembly.

Members of the committee, except the representative of the governor and the state commissioners, should serve for a fixed period renewable not more than once. On being appointed, members should, save for death, resignation, criminal conviction and/or infirmity, have a secured tenure of office and only be liable to be removed by the governor on the recommendation of simple majority of members of the State House of Assembly. With such broad-based membership and statutory powers of the committee, the hitherto excessive powers of the governor will be curtailed. Land management in the state will come to resemble the wishes and aspirations of the members of the public as it will infuse more public participation in land administration in the state. Such representation will also ensure a constant feedback and a crisscross of opinion on land administration between the government and the governed and thus reduce conflicts in land matters.

To ensure fairness and equity in the exercise of the penal revocation powers of the governor, the court should be handed the responsibility to revoke or otherwise order the judicial sale of the right of occupancy on the application of the governor. The twin pillars of natural justice doctrine ${ }^{106}$ should be respected in the circumvention of private property rights. The governor's adjudicatory powers under the Act should be repealed.

106 Audi alterem partem and Nemo judex in causa sua. See Sayani Mitra, "Protecting the Rule of Natural Justice" (2011) SSRN <https://ssrn.com/ abstract $=1743442>$ accessed 25 April 2018. 


\section{CONCLUSION}

The current system of land administration under the Land Use Act is bereft of any clear and coherent policy direction. It is politically undemocratic, economically unproductive, but also socially segregative, particularly in its urban and non-urban dichotomy. In view of the need to diversify the Nigerian economy, unleash the nation's potentials in the non- oil sector and enlarge access to land for the purposes of agriculture development and infrastructural investment in Nigeria, there is a need to streamline the extant land policy and administration in Nigeria. Only a vibrant land administration policy can give impetus to the current socio-economic policy options of the government, otherwise, the vicious circle of poverty and homelessness that pervades the country will persist. Given the observed lacuna and inconsistency in the provisions of the Act, the article calls for legislative intervention by way of reform to review the provisions of the Act in line with recommendations discussed in the preceding section. 